\title{
НАРОДНІ ТАНЦІ ДОЛИНЯН ЯК ДЖЕРЕЛО СТВОРЕННЯ НАРОДНО-СЦЕНІЧНИХ КОМПОЗИЦІЙ
}

\author{
Тимчула Андрій Васильович, \\ кандидат мистецтвознавства, викладач, \\ Київський національний університет культури і мистецтв, \\ Київ, Україна, \\ https://orcid.org/0000-0002-8287-6852, \\ tymchula_adukr.net \\ Гутник Ірина Миколаївна, \\ кандидат педагогічних наук, доцент, \\ Київський національний університет культури і мистецтв, \\ Київ, Україна, \\ https://orcid.org/0000-0001-6492-370X, \\ i.gutnyk@ua.fm
}

\begin{abstract}
Мета статті - виявити специфіку народного танцю долинян як фольклорного першоджерела народно-сценічних хореографічних постановок. Методологія. Відповідно до специфіки мети та завдань дослідження застосовано типологічний метод, спрямований на виявлення місцевих особливостей традиційної долинної культури, відповідно до їх етнографічного районування; порівняльно-історичний метод (для порівняльного аналізу народної хореографічної культури місцево-територіальних груп долинян у контексті календарних та сімейних обрядів в історичному контексті); жанрово-типологічний метод (для аналізу особливостей відтворення різноманітного фольклорного танцювального матеріалу долинян у постановках народно-сценічних танців. Наукова новизна. Уперше виявлено структурно-стилістичні особливості традиційної народної хореографічної культури долинян відповідно до районування, проаналізовано хореографічні елементи, фігури, кроки й рухи. Висновки. Своєрідність хореографічної лексики долинян внаслідок впливу багатьох об'єктивних та суб'єктивних факторів протягом багатьох століть формувалася в умовах впливу танцювальної культури мадяр, румунів та гуцулів (характерно для локально-територіальної групи марамороські долиняни), угорців та словаків (боржавські й ужанські долиняни), а також специфічних особливостей лемківської та бойківської культури (перечинсько-березанські долиняни). Виявлено яскраві хореографічні виражальні засоби ритуальних та обрядових танців, серед яких «Увиванець» (довжанські долиняни), «Людська сколомийка», «Меньосоньтанц» (боржавські долиняни) та ін. Представлена студія не вичерпує всіх аспектів проблеми й може використовуватись у подальшому дослідженні питань, пов'язаних з розвитком народної хореографічної культури долинян та українців в цілому, а також стати основою для культурологічних та мистецтвознавчих розвідок з історії української хореографії, етнохореології, етнокультуралогії, хореопедагогіки та ін.
\end{abstract}

Ключові слова: народні танці долинян; народно-сценічні танці; українські танці; хореографія. 


\section{НАРОДНЫЕ ТАНЦЫ ДОЛИНЯН КАК ИСТОЧНИК СОЗДАНИЯ НАРОДНО-СЦЕНИЧЕСКИХ КОМПОЗИЦИЙ}

\author{
Тымчула Андрей Васильевич, \\ кандидат искусствоведения, преподаватель, \\ Киевский национальный университет \\ культуры и искусств, \\ Киев, Украина, \\ https://orcid.org/0000-0002-8287-6852, \\ tymchula_adukr.net
}

Гутник Ирина Николаевна,

кандидат педагогических наук, доцент,

Киевский национальный университет

культуры и искусств,

Киев, Украина,

https://orcid.org/0000-0001-6492-370X,

i.gutnyk@ua.fm

Цель статьи - выявить специфику народного танца долынян как фольклорного первоисточника народно-сценических хореографических постановок. Методология. В соответствии со спецификой целей и задач исследования применены типологический метод, направленный на выявление местных особенностей традиционной долинной культуры, в соответствии с этнографическим районированием; сравнительно-исторический метод (для сравнительного анализа народной хореографической культуры территориальных групп долынян в контексте календарных и семейных обрядов в историческом контексте), жанрово-типологический метод (для анализа особенностей воспроизведения разнообразного фольклорного танцевального материала долынян в постановках народно-сценических танцев). Научная новизна. Впервые выявлено структурно-стилистические особенности народной хореографической культуры долынян согласно районированию, проанализированы хореографические элементы, фигуры, шаги и движения. Выводы. Своеобразие хореографической лексики долынян в результате воздействия многих объективных и субъективных факторов в течение многих веков

\section{FOLK DANCES OF DOLYNIANS AS A SOURCE OF FOLK AND STAGE COMPOSITIONS CREATION}

\author{
Andrii Tymchula, \\ PhD in Art Studies, Lecturer, \\ Kyiv National University \\ of Culture and Arts, \\ Kyiv, Ukraine, \\ https://orcid.org/0000-0002-8287-6852, \\ tymchula_adukr.net \\ Iryna Gutnyk \\ PhD in Pedagogy, \\ Associate Professor, \\ Kyiv National University of Culture and Arts, \\ Kyiv, Ukraine, \\ https://orcid.org/0000-0001-6492-370X, \\ i.gutnykฉua.fm
}

The purpose of the article is to reveal the specifics of Dolynian folk dance as a folklore primary source of folk stage choreographic performances. Methodology. Following the specifics of the goals and objectives of the study, a typological method was applied, aimed at identifying the local features of the traditional Dolynian culture, in accordance with ethnographic zoning; the comparative historical method (for a comparative analysis of the folk choreographic culture of Dolynian territorial groups in the context of calendar and family rites in a historical context), the genre-typological method (for analyzing the reproduction features of various folklore dance material of Dolynians in the performances of folk stage dances). Scientific Novelty. For the first time, the structural and stylistic features of the traditional folk choreographic culture of Dolynians in accordance with the zoning were revealed; the choreographic elements, figures, steps and movements were analyzed. Conclusions. The originality of Dolynian choreographic vocabulary, as a result of the influence of many objective and subjective factors, for many centuries was formed in the conditions of the influence of the dance culture of Magyars, Romanians and Hutsuls (typical for the local-territorial group of Maramoros Do- 
формировалось в условиях воздействия танцевальной культуры мадьяр, румын и гуцулов (характерно для локально-территориальной группы марамороские долыняне), венгров и словаков (боржавские и ужанские долыняне), а также специфических особенностей лемковской и бойковской культуры (перечинско-березанские долыняне). Выявлено яркие хореографические выразительные средства ритуальных и обрядовых танцев, среди которых «Увиванець» (должанские долыняне), «Людська сколомийка», «Меньосоньтанц» (боржавские долиняне) и др. Представленная студия не исчерпывает всех аспектов проблемы и может использоваться при дальнейшей разработке вопросов, связанных с развитием народной хореографической культуры долынян и украинцев в целом, а также стать основой для культурологических и искусствоведческих исследований по истории украинской хореографии, етнохореологии, етнокультуралогии, хореопедагогике и др.

Ключевые слова: народные танцыы долынян; народно-сценические танцы; украинские танцы; хореография. lynians), Hungarians and Slovaks (Borzhava and Uzhan Dolynians), as well as the specific features of the Lemko and Boyko culture (Perechynsk-Berezan Dolynians). Bright choreographic means of expression of ritual and ceremonial dances were revealed, among which "Uvyvanets" (Dovzhansky Dolynians), "Liudska skolomyika", "Menosontants" (Borzhava Dolynians) and others. The presented study does not cover all aspects of the problem and can be used in further research on issues related to the development of the folk choreographic culture of Dolynians and Ukrainians in general, as well as become a basis for cultural and artistic research on the history of Ukrainian choreography, Ethnochoreology, Ethnocultural Studies, Choreographic Pedagogy, etc.

Keywords: folk dances of Dolynians; folk stage dances; Ukrainian dances; choreography.

Актуальність теми дослідження. Об’єктивне висвітлення специфіки процесу формування й розвитку народного хореографічного мистецтва українців Закарпаття другої половини XX - початку XXI ст. украй необхідне в сучасних умовах нівелювання особливостей культури різних територій, що пов'язано із глобалізаційними процесами. Особливої актуальності набуває виявлення специфіки локальної хореографічної лексики етнографічної групи долинян та проведення мистецтвознавчого аналізу народно-сценічного мистецтва українських балетмейстерів зазначеного періоду в аспекті використання фольклорних першоджерел долинян відповідно до їх районування.

Аналіз останніх досліджень та публікацій засвідчив відсутність наукових праць, присвячених вивченню особливостей народних та народно-сценічних танців долинян. На сучасному етапі у вітчизняному науковому вимірі, назважаючи на посилення протягом останніх років інтересу культурологів та мистецтвознавців до традиційної танцювальної культури українців, специфіка фольклорних танців долинян у контексті традиційної обрядовості, на жаль, не отримала наукового висвітлення. Окремі аспекти означеної проблематики аналізувалися в дослідженнях традиційної обрядовості українців Закарпаття, здійснених С. Боян (2010), І. Бугерою (Бугера, 1997), І. Волицькою (Волицька, 1992), О. Коломийчук (2013), Т. Леньо (2013), А. Тимчулою (2021) та ін. Праці цих науковців, хоча і не містять детальних описів танцювальних елементів, представляють неабияку 
цінність у контексті нашого дослідження, оскільки посприяли уточненню розуміння місця і значимості народних танців у культурі долинян..

Мета статті - виявити специфіку народного танцю долинян як фольклорного першоджерела народно-сценічних хореографічних постановок.

Виклад основного матеріалу. Долиняни - етнографічна група українців, яка разом із гуцулами, бойками та лемками районується на південних схилах Карпат. Із XIII ст. долиняни, які, за припущеннями вітчизняних істориків (О. Сабо, М. Тиводар та ін.), походять від семиградських слов'ян (Szabo, 1913, с. 26) або східнослов'янських племен (Тиводар, 2010, с. 47-50), населяють території рівнин, передгір’я та невелику частину середньогір'я й високогір'я Карпат. За свідченням дослідника М. Тиводара, із середини XX ст. долиняни називають себе закарпатськими українцями, районуючись на землях колишніх Березького, Марамороського, Замплинського, Угочанського та Ужанського комітатів (Тиводар, 1999, с. 35).

Традиційна культура долинян загалом і танцювальна зокрема, через неоднорідність територіального районування, специфіку історичних особливостей і впливів інших народів та етнографічних груп, характеризується певними відмінностями не лише від культури бойків, лемків та гуцулів, а й специфічними особливостями хореографічної лексики між локально-територіальними групами (боржавські, марамороські, перечинсько-березанські та ужанські долиняни) в межах власної етнографічної групи (Тиводар, 1999, с. 36-44).

Розглядаючи народний танець долинян як фольклорне першоджерело народно-сценічних хореографічних постановок, вважаємо за доцільне проаналізувати танці в контексті традиційної календарної й родинно-побутової обрядовості, оскільки стародавні форми світобачення та світосприйняття, обряди, вірування та звичаї, що відчутно вплинули на формування танцювальної культури, завдяки особливому ставленню долинян до власних традицій, залишилися незмінними і на сучасному етапі.

Українські народні традиції, звичаї, ритуали та обряди, що протягом багатьох століть були пов'язані з календарним та життєвим циклом, поділяються на сімейні, сезонні (землеробські) та громадські (події з життя спільноти).

Календарна обрядовість становить собою складний фольклорний комплекс, у якому релігійні й магічні вірування, звичаї і традиції поєднуються з раціональним досвідом (Курочкін, 1993, с. 182). Усталене протягом століть, на основі процесів життєдіяльності людини (вшанування культу предків, заготівельні роботи, весільний сезон) і трудового сільськогосподарського календаря, відповідно до сезонності природи, річне коло зимових, весняних, літніх та осінніх свят, обрядів та звичаїв в календарі долинян формально узгоджувались із річним літургічним циклом православної церкви.

Аналізуючи календарну обрядовість долинян, можемо зробити висновок, що свята зимового (Різдво, Василя, Водохреща, Стрітення Господнє), весняного (ранні - Сорок Святих, Теплого Олекси та пізні - Благовіщення, Вербна неділя, Живний четвер, Великдень, Юрія, Миколая), літнього (Зелені свята, Івандень, Петра і Павла, Маковій, Іллі, Спас) та осіннього (Покрова, Дмитрія, Введення, Михайла, Катерини, Андрія, Варвари, Миколая) циклів, а відтак і типові для кожного свята прикмети, ритуали, обряди (відповідно до смислового навантаження), пісні, заклинання й танці, що їх супроводжували, залежали в першу чергу від особливос- 
тей моральної, духовної й традиційної господарської культури цієї етнографічної групи. Поділ календарних свят на сезонні не був усталеним і залежав від районування та інших аспектів, зокрема завершення аграрно-господарських робіт.

Традиційним танцем календарної обрядовості зимового циклу марамороських долинян (особливо в районі Хустщини) був «Сухий танець» - під час Різдвяного посту його зазвичай виконували під акомпанемент сопілки та дримб.

Значущим у весняній календарній обрядовості долинян мало Свято святого Власія (24 лютого) - покровителя лісових звірів та бідних людей (Воропай, 1993, c. 147-148), яке відзначали і до прийняття християнства - на честь покровителя домашньої худоби Велеса, а в процесі трансформації та відповідно до світогляду українців Закарпаття стало святом покровителя всіх тварин, особливо крупної рогатої худоби.

У марамороських долинян, через переважання в господарській культурі відгінно-полонинського типу скотарства практично відсутні танцювальні обряди весняного й літнього циклів, виключенням $є$ традиційні гаївки, які присвячені возвеличенню сили сонця, оновленню природи, її пробудженню та приходу весни. Вони супроводжувалися виконанням хороводів, хореографічна будова яких «криве колесо», проте наявні аналогічні із землеробськими східнослов'янськими обрядами різдвяні та йорданські колядки.

Марамороським долинянам властиві деякі обряди їхніх безпосередніх сусідів - рахівських гуцулів. Підтвердження цьому дає праця австрійського науковця Г.-І. Бідермана «Die ungarischen Ruthenen, ihr Wohngebiet, ihr Erwerb und ihre Geschichte» (1862), у якій він описує історію, традиційну культуру, побут, промисли й територію проживання закарпатських українців. Дослідник стверджує, що, відзначаючи свято Івана Хрестителя (5 липня), горяни Мармароського, Березького та Ужанського комітатів влаштовують у передвечір свята танці довкола багаття (купальських вогнищ), які розпалюють на найвищих гірських вершинах: «дівчата, прикрашені квітами, беруться за руки i, співаючи, пританцьовують довкола багаття, а хлопці у той час б'ють дерев'яними молотами по розпечених вугляках» (Бідерманн, 2006, с. 429-430), називаючи цей звичай «Купайло» або «Собітки».

В іршавських долинян під час весняного циклу традиційно відбувалися ігрові танці - водіння дівочих хороводів біля водоймищ («Жучок», «Вербова дощечка», «Огірочки», «Сосна», «Груша», «Чоловік і дружина» та ін.), участь у яких брали усі жінки та дівчата сусідніх сіл.

Саме з хороводів, поєднаних із календарно-обрядовою лірикою, виникли танцювальні пісні, у яких органічно співіснують поетичні, музичні й хореографічні елементи на основі спільних ритмічних форм, що протягом століть супроводжували календарні обряди українців Закарпаття. Відповідно до функціональних параметрів танцювальних пісень, зумовлених регіональними особливостями, найпоширенішими в обрядовому контексті в долинян були сколомийки.

Для долинян велике значення мали ритуали весільної обрядовості (весільні ритуали), що характеризуються сублімуванням народно-пісенної та хореографічної творчості, вірувань та традицій.

У довжанських долинян (територіально-популяційна група боржавських долинян) весілля традиційно відбувалося у вівторок або четвер, а в понеділок або середу (відповідно) - дружківський вечір. Спочатку дружби разом із дружками заходили 
на пригощання до хати нареченої, а потім разом з нею та її родичами - до хати нареченого, куди також обов'язково приходив гонноть (староста) і музиканти. Звідти процесія вирушала по барвінок, вінки з якого плелися потім у хаті молодого під традиційне ладкання 3 музичним супроводом. Саме після обряду вінкоплетіння довжанські долиняни збиралися на подвір'ї, щоб танцювати перший ритуальний танець (заігрування молодих, які під час нього тримали в руках зав'язану колом хустку, на яку нанизані вінки) - «Увиванець», фігурою якого було замкнуте коло. Учасники, тримаючись за руки, «робили каріку» (від угорського karika - коло), а в центр кола староста клав гроші й накривав їх старим піджаком батька молодого, який кожен із учасників мав бити ногами під час танцю (Керечанин, 2016, с. 901). По завершенні цього обряду для молодої, дружок, усіх дівчат та жінок із родини молодої розпочиналися гуски (дівочий вечір, на якому чоловіків не більше трьох). Молодий, дружби та хлопці лишалися танцювати і співати на подвір’ї до наступного ранку (Симоненко, 1946, с. 126). У день весілля, після вінчання та весільного частування, наступав час танцювати (традиційно це відбувалося не в хаті, а на подвір'і).

Особливо цікавою є традиція виконання чоловіками динамічної й енергійної «Людської сколомийки», у якій поєднано хореографію, міміку та спів - танцюючи і підспівуючи вони щосили стукали у стріху. Аналізуючи особливості виконання сколомийки, відзначимо постійно зростаючий темп, обов’язкову синхронність рухів, а також виконання кожним із учасників лише однієї строфи пісні (що пояснюється швидким темпом) (Львова, 2012, с. 440). Варто зазначити, що сколомийки (короткі пісеньки до танцю, які складаються 3 двох рядків по 14-ть слів у кожному) - специфічний різновид поширеної на Закарпатті коломийки, властивий лише певним територіально-популяційним групам боржавських долинян - довжанській та іршавській.

Танець молодої - «Шоровий» танець, традиційний для усіх українців Закарпаття, у боржавських долинян називався «Меньосоньтанц» (у перекладі з угорської - танець молодої) і виконувався під коломийку. Молоду, після обряду знімання вінків, до цього танцю запрошували гудаки; спершу вона танцювала саме зі старостою, який потім, доки молода танцювала зі всіма бажаючими, збирав із них гроші (Керечанин, 2016, с. 904).

У перечинсько-березнянських долинян під час весільної ходи - процесії до церкви, традиційним було «підтанцьовування»- виконання певних комбінацій рухів, які символізували пошану до молодої пари та створювали святкову атмосферу, під музичний (інструментальний) або пісенний супровід (найпопулярнішою формою, і музичною, і танцювальною, у першій половині XX ст. був чардаш (Bellman, 2001, с. 759) - помітний безумовний вплив угорської культури.

Рухи зазвичай були запозичені з інших танців і виконання мало імпровізаційний характер. Найпопулярнішим із них, а відтак можемо визначити його як основний елемент «підтанцьовування», була трясучка (рух у певних модифікаціях широко розповсюджений в угорських та румунських танцях-ходах), або, за визначенням А. Гуменюка, закарпатські дрібушки (Гуменюк, 1969, с. 67). До речі, трясучка $є$ основним танцювальним елементом народно-сценічного танцю «Березнянка» (авторська хореографія П. Вірського та К. Балог, 1964 р.), одним із рухів ходу вперед у «Тропотянці» (балетмейстер М. Ромадов, 1950 р.), а також зустрічається у постановках «Дуботанцю» (балетмейстери Й. Волощук, 1960 р.; І. Попович, 1968-1969рр.). 
У творчості балетмейстерів-постановників другої половини XX - початку XXI ст. фольклорні танці долинян стали основою створення народно-сценічних композицій: «Увиванець» (довжанські долиняни); «Людська сколомийка», «Меньосоньтанц», «Бубнярський», «Кумлуський чардаш», «Раковецький кручений», «Чотирянка» (боржавські долиняни); «Яроцька карічка» (ужанські долиняни); «Березнянка», «Дробойка», «Турянський», «Чардаш з Парховане», (перечинсько-березнянські долиняни); «Сіпаний» (хустські долиняни); «Затанцьовування свадьби», «Золотий танець», «Легінський танець на гуні», «Сухий танець» (марамороські долиняни).

Наукова новизна. Уперше виявлено структурно-стилістичні особливості традиційної народної хореографічної культури долинян відповідно до районування, проаналізовано хореографічні елементи, фігури, кроки й рухи.

Висновки. Дослідження виявило, що своєрідності хореографічної лексики долинян, внаслідок впливу багатьох об’єктивних та суб’єктивних факторів, протягом багатьох століть формувалася в умовах впливу танцювальної культури мадяр, румунів та гуцулів (характерно для локально-територіальної групи марамороські долиняни), угорців та словаків (боржавські й ужанські долиняни), а також специфічних особливостей лемківської та бойківської культури (перечинсько-березанські долиняни).

Дослідження календарної та родинно-побутової обрядовості долинян дало змогу виявити яскраві хореографічні виражальні засоби ритуальних та обрядових танців, зокрема специфіку танців «Увиванець» (довжанські долиняни), «Людська сколомийка», «Меньосоньтанц» (боржавські долиняни) та ін.

Представлена студія не вичерпує всіх аспектів означеної проблеми й може використовуватись у подальшому осмисленні питань, пов'язаних з розвитком народної хореографічної культури долинян та українців у цілому, а також стати основою для культурологічних і мистецтвознавчих розвідок з історії української хореографії, етнохореології, етнокультуралогії, хореопедагогіки та ін.

\section{СПИСОК ПОСИЛАНЬ}

Бідерманн, Г. І. (2006). Закарпатські українці, територія їхнього проживання, їхні промисли та їхня історія (А. Вовчак, пер.). Вісник Львівського університету. Серія філологічна, 37, 421-449.

Воропай, О. (1993). Звичаї нашого народу: Етнографічний нарис. Оберіг.

Гуменюк, А. (Упоряд.). (1969). Українські народні танці. Наукова думка.

Керечанин, І. (2016). Традиційне весілля українців села Кушниця в контексті сімейної обрядовості Закарпаття. Народознавчі зошити, 4(130), 897-905.

Курочкін, О. (1993). Свята й обряди календарного циклу. В А. Пономарьов (Ред.), Українська минувшина: Ілюстрований етнографічний довідник (с. 182-201). Либідь.

Львова, К. (2012). Діонісійське походження сороміцьких сколомийок села Приборжавського, Іршавського району, Закарпатської області. Література, фольклор, проблеми поетики, 36, 438-443.

Симоненко, И. Ф. (1946). Свадебные обряды в Закарпатской области. Советская этнография, 4, 125-141.

Тиводар, М. П. (1999). Етнографічне районування українців Закарпаття (за матеріалами традиційної культури другої половини XIX - першої половини XX ст.). Carpatica-Kapпатика, 6, 4-64.

Тиводар, М. П. (2010). Етнографія Закарпаття: Історико-етнографічний нарис. Гражда. 
Тимчула, А. (2021). Народне хореографічне мистецтво українців Закарпаття другої половини $X X-$ початку XXI століття [Дисертація кандидата мистецтвознавства]. Київський національний університет культури і мистецтв, Київ.

Bellman, J. (2001). Csárdás. In The New Grove Dictionary of Music and Musicians (Vol. 6; p. 759). Oxford University Press.

Szabó, O. (1913). A magyar oroszokrol (Ruthének).

\section{REFERENCES}

Bellman, J. (2001). Csárdás. In The New Grove Dictionary of Music and Musicians (Vol. 6; p. 759). Oxford University Press.

Bidermann, H. I. (2006). Zakarpatski Ukraintsi, Terytoriia Yikhnoho Prozhyvannia, Yikhni Promysly ta Yikhnia Istoriia [Transcarpathian Ukrainians, Their Territory of Residence, Their Trades and Their History] (A. Vovchak, Trans.). Visnyk Lvivskoho Universytetu. Seriia Filolohichna [Visnyk of the Lviv University. Series Philology], 37, 421-449 [in Ukrainian].

Humeniuk, A. (Comp.). (1969). Ukrainski Narodni Tantsi [Ukrainian Folk Dances]. Naukova dumka [in Ukrainian].

Kerechanyn, I. (2016). Tradytsiine Vesillia Ukraintsiv Sela Kushnytsia v Konteksti Simeinoi Obriadovosti Zakarpattia [Traditional Wedding of Ukrainians of Kushnytsia Village in the Context of Family Rituals of Transcarpathia]. Narodoznavchi Zoshyty [Ethnographic Notebooks], 4(130), 897-905 [in Ukrainian].

Kurochkin, O. (1993). Sviata y Obriady Kalendarnoho Tsyklu [Holidays and Ceremonies of the Calendar Cycle]. In A. Ponomarov (Ed.), Ukrainska Mynuvshyna: Iliustrovanyi Etnohrafichnyi Dovidnyk [Ukrainian Past: Illustrated Ethnographic Guide] (pp. 182-201). Lybid [in Ukrainian].

Lvova, K. (2012). Dionisiiske Pokhodzhennia Soromitskykh Skolomyiok Sela Pryborzhavskoho, Irshavskoho Raionu, Zakarpatskoi Oblasti [Dionysian Origin of the Shameful Skolomyiky of Pryborzhavske Village, Irshava District, Zakarpattia Region]. Literatura, Folklor, Problemy Poetyky [Literature, Folklore, Problems of Poetics], 36, 438-443 [in Ukrainian].

Simonenko, I. F. (1946). Svadebnye Obryady v Zakarpatskoi Oblasti [Wedding Ceremonies in the Transcarpathian Region]. Sovetskaya Etnografiya [Soviet Ethnography], 4, 125-141 [in Russian].

Szabó, O. (1913). A Magyar Oroszokrol (Ruthének) [About the Hungarian Russians (Ruthenians)] [in Hungarian].

Tymchula, A. (2021). Narodne Khoreohrafichne Mystetstvo Ukraintsiv Zakarpattia Druhoi Polovyny XX - Pochatku XXI Stolittia [Folk Choreographic Art of Ukrainians of Transcarpathia in the Second Half of the XX - Beginning of the XXI Century] [PhD Dissertation]. Kyiv National University of Culture and Arts, Kyiv [in Ukrainian].

Tyvodar, M. P. (1999). Etnohrafichne Raionuvannia Ukraintsiv Zakarpattia (za Materialamy Tradytsiinoi Kultury Druhoi Polovyny XIX - Pershoi Polovyny XX st.) [Ethnographic Zoning of Ukrainians in Transcarpathia (Based on the Materials of Traditional Culture of the Second Half of the XIX - First Half of the XX Century)]. Carpatica-Karpatyka, 6, 4-64 [in Ukrainian].

Tyvodar, M. P. (2010). Etnohrafiia Zakarpattia: Istoryko-Etnohrafichnyi Narys [Ethnography of Transcarpathia: Historical and Ethnographic Essay]. Grazhda [in Ukrainian].

Voropai, O. (1993). Zvychai Nashoho Narodu: Etnohrafichnyi Narys [Customs of Our People: Ethnographic Essay]. Oberih [in Ukrainian]. 